\title{
Penerapan ARTificial InTELligenCE DALAM COMPUTER AIDED INSTRUCTURE(CAI)
}

\author{
Chanda Halim ${ }^{1}$, Hendri Prasetyo ${ }^{2}$ \\ Jurusan Teknik Informatika \\ STMIK IKMI \\ chandra_h@yahoo.com, hendrip@yahoo.com
}

\begin{abstract}
Abstrak-Dengan perkembangan teknologi komputer dan informasi, Artificial Intelligence (AI) digunakan dalam teknik pendidikan, dan telah menjadi kecenderungan pengembangan pendidikan komputer. Makalah ini memperkenalkan sistem instruksi dibantu komputer dan aktualitasnya, dan membahas konsepsi, objek penelitian dan ruang lingkup AI, kemudian berurusan dengan instruksi dibantu komputer cerdas berdasarkan kecerdasan buatan, akhirnya mengusulkan beberapa jenis Computer Aided Instructure(CAI).
\end{abstract}

Keyword-CAI, Artificial Intelligence

\section{Pendahuluan}

Di banyak bidang ilmu komputer, kecerdasan buatan (AI) adalah bidang yang menantang dan kreatif. Dengan kelahiran dan pengembangan kecerdasan buatan, orang mulai area komputer untuk instruksi. Untuk membuat reformasi instruksi untuk beradaptasi dengan itu, kita perlu memperkenalkan metode instruksi tingkat lanjut, penggunaan sistem instruksi dibantu komputer (CAl) dapat memberikan lingkungan instruksi yang ideal, mudah untuk merangsang antusiasme dan inisiatif siswa untuk belajar, sehingga secara signifikan meningkatkan efek instruksi. Meningkatnya perkembangan teknologi multimedia, serta integrasi dengan teknologi terkemuka lainnya pasti akan mendorong pengembangan lebih lanjut dari $\mathrm{CAl}$, Dalam makalah ini, untuk beberapa prospek $\mathrm{CAl}$, dengan penekanan pada teknologi kecerdasan buatan untuk CAl cerdas, kami memberikan ide dan pemikiran implementasi.

\section{STUdi Literatur}

A. Konsep Kecerdasan Buatan

Kecerdasan buatan adalah cabang ilmu komputer, adalah disiplin terpadu yang mempelajari cara menggunakan komputer untuk mensimulasikan dan memperluas fungsi otak manusia. Definisi yang tepat adalah: sistem komputer memiliki pengetahuan dan perilaku manusia dengan kemampuan seperti belajar, penyimpangan, penilaian, menyelesaikan masalah, memori, pengetahuan dan pemahaman bahasa alami manusia.

B. Objek Penelitian dan Ruang Lingkup

Pelajari program komputer yang dapat membaca dan menulis, yang sering disebut sebagai area Natural Language Processing(NLP) atau pemrosesan bahasa alami. Pengembangan peralatan sensitif, melalui robot dengan prosedur visual dan pendengaran, untuk mengidentifikasi perubahan lingkungan dalam kegiatan;

Pengembangan Character Recognition digunakan untuk mensimulasikan perilaku ahli manusia dalam prosedur [4] - [5] [6] [7], yaitu sistem pakar. Namun, dari sifat penelitian, kecerdasan buatan secara umum dapat dibagi menjadi penelitian teoritis dan studi teknik dua aspek. Penelitian teoritis terutama terkait dengan pengembangan dan pemahaman teori kecerdasan manusia dan mesin, penelitian dan eksplorasi, dan studi teknik terutama terkait dengan desain dan pengembangan dan penelitian alat sistem 
pakar kecerdasan buatan dan produk-produk tersebut. Namun, ini tidak berarti bahwa mereka independen satu sama lain; sebaliknya, mereka saling bergantung dan tak terpisahkan. Ketika teori dan teknologi kecerdasan buatan telah diadopsi secara bertahap, dan secara khusus untuk mengembangkan produk, teori, dan batas-batas antara penelitian rekayasa akan berkurang, sampai menghilang. Untuk menunjukkan dalam dua jenis studi yang berbeda, orang yang terlibat dalam penelitian teoritis menggunakan "peneliti kecerdasan buatan", istilah, sementara para petugas yang terlibat dalam penelitian rekayasa secara kolektif disebut sebagai "insinyur pengetahuan".

C. Tiga Masalah Utama yang Diperbaiki untuk Penelitian

- Intelijen pemrosesan informasi. Untuk memeriksa input dan output informasi, serta penyimpanan informasi dan informasi metode pemrosesan internal.

- pengolahan simbol. Pemrosesan simbol menekankan peran penting dari simbol dalam pemrosesan informasi. Komputer memiliki performa input, output, penyimpanan, penyalinan dan pembandingan simbol.

- Kecerdasan pengobatan pemecahan masalah. Penelitian kecerdasan manusia dan mesin memungkinkan kami mencari tahu bagaimana orang dan mesin untuk memecahkan masalah tertentu.

\section{COMPUTER AIDED INSTRUCTION (CAI)}

A. Sistem Instruksi Berbantuan Komputer

Computer Aided Instruction (CAl) menggunakan komputer yang mensimulasikan perilaku guru dengan fitur dan karakteristik komputer multimedia, alih-alih guru untuk peserta didik, dan untuk mencapai tujuan pembelajaran yang lebih baik dengan siswa dalam kegiatan interaktif.

Penggunaan sistem CAl dapat memainkan peran utama dalam merangsang minat dan pemahaman siswa, itu menyediakan keragaman rangsangan eksternal yang kondusif untuk akuisisi pengetahuan dan konservasi, sehingga dapat secara signifikan meningkatkan efek instruksi. Luar negeri, CAl courseware telah banyak digunakan di sekolah, keluarga, dan menerima hasil yang baik. Di Cina, meskipun terlambat memulai $\mathrm{CAl}$, tetapi telah berkembang pesat.

B. Status instruksi berbantuan komputer

CAl tradisional menempatkan semua informasi instruksi secara terprogram di courseware, seperti $\mathrm{CAl}$ courseware Setelah selesai, meningkatkan instruksi akan memberikan ketidaknyamanan yang besar untuk pekerjaan pemeliharaan yang signifikan. Oleh karena itu, sistem CAl yang ada menghadapi banyak tantangan karena teknologi baru, terutama aspek-aspek berikut.

(1) Kurangnya kapasitas interaksi komputer manusia

Sebagian besar pembawa informasi CAl yang ada adalah CD ROM, isi buku teks muncul dalam bentuk multimedia, instruksi informasi didasarkan pada instruksi proses pra-mekanis yang tersedia untuk siswa, siswa yang menggunakan $\mathrm{CAl}$ courseware juga merupakan pembelajaran pasif. Sementara di kelas instruksi, umumnya proses courseware dijadwalkan untuk beroperasi, baik siswa dan guru tidak terlibat dengan baik dalam proses pembelajaran dan instruksi, sehingga interaksi komputer manusia tidak terealisasi dengan baik.

(2) Kurangnya interaksi guru-murid

Cara belajar sesuatu milik siswa sendiri dalam belajar mandiri siswa, untuk penggunaan operasional dengan perkapalan CAl yang ada. Guru tidak dapat sepenuhnya menyadari kasus siswa, 
ketika siswa mengalami masalah, kita juga tidak dapat membantu untuk guru, antara guru dan siswa yang saling tertutup, belum lagi interaksi siswa-guru, sehingga efek positif perangkat lunak sangat berkurang. Tetapi juga karena kurangnya dukungan jaringan, sebagian besar dari perkuliahan CAl yang ada berjalan di lingkungan yang berdiri sendiri, dan mereka tidak dapat menggunakan kelebihan Internet untuk memperbarui pengetahuan dengan cepat, tentu saja, dan tidak dapat menyediakan ruang yang nyaman untuk belajar dan diskusi, kapan saja, di mana saja sarana komunikasi, serta pembelajaran jarak jauh siswa untuk mencapai kondisi.

(3) Kurangnya kecerdasan

Untuk menghadapi situasi yang berbeda dari siswa di berbagai tingkat pendidikan, proses pengajaran, sehingga pembelajaran siswa menjadi aktif, dan dapat secara otomatis memberikan informasi siswa untuk studi selektif oleh sistem; Untuk membuat guru terlibat dalam instruksi sesuai dengan informasi yang diberikan oleh sistem berdasarkan pada siswa untuk mempersiapkan model kognitif dari konten pembelajaran yang paling sesuai, memberikan berbagai cara model dan metode instruksi, jika tidak ada kecerdasan dari sistem courseware, sulit untuk mencapai tujuan di atas dan mencapai efek instruksi yang baik. Banyak masalah dari CAl yang ada tidak dapat semakin memenuhi persyaratan baru dengan munculnya teknologi baru secara berkelanjutan.

\section{INTELLIGENT COMPUTER AIDED INSTRUCTION(ICAI)}

ICAI (Intelligent Computer Aided Instruction) didasarkan pada ilmu kognitif, menggunakan teknologi kecerdasan buatan di CAl, itu adalah CAL ICAI yang cerdas akan memberikan siswa dengan jenis baru lingkungan belajar, sesuai dengan karakteristik pembelajaran siswa, sejarah pembelajaran dan gaya belajar, itu dapat menggunakan metode dan strategi pengajaran yang berbeda untuk lebih memenuhi kebutuhan yang berbeda dari peserta didik yang berbeda, untuk mendiagnosis kesalahan pembelajar, untuk menentukan penyebab kesalahan, untuk menghasilkan strategi koreksi yang sesuai dan lebih baik mencerminkan prinsip-prinsip instruksi sesuai dengan kemampuan dan berorientasi pada individu. 


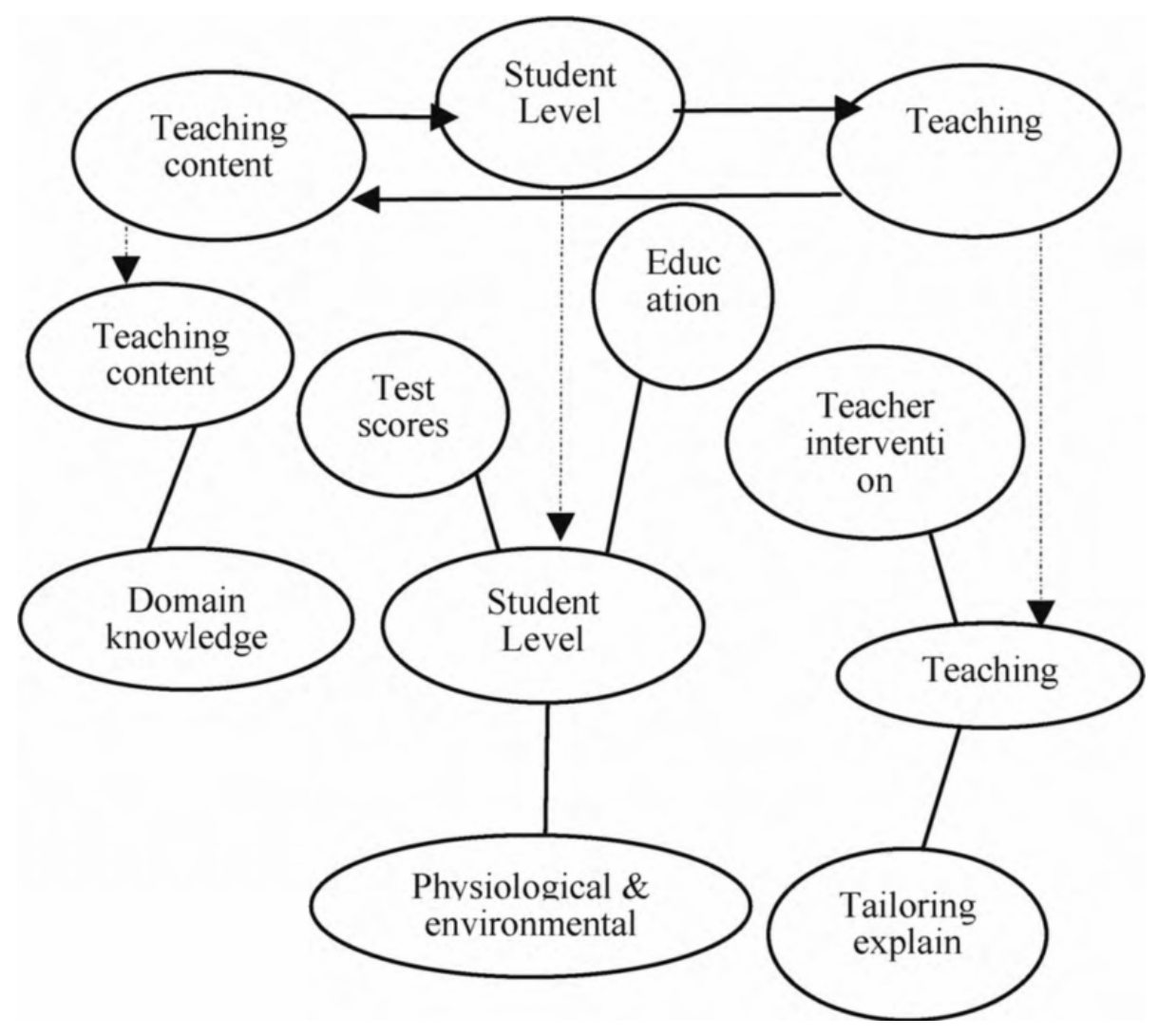

Gambar 1: Karakteristik Instruksi

Karakteristik utama dari instruksi ICAI dapat memberikan bimbingan individu untuk siswa, dan untuk melakukan ini, kita harus tahu apa yang harus diajarkan dan memahami siswa dan akrab dengan metode pengajaran. Oleh karena itu, model pembelajaran yang baik harus ditunjukkan pada Gambar 1., yaitu, guru pertama memahami standar siswa, dan kemudian memilih metode instruksi sesuai dengan tingkat siswa, pilih konten instruksi sesuai dengan metode pengajaran, sesuai dengan konten membuat eksperimen dan pertanyaan, dan akhirnya menilai tingkat siswa master sesuai dengan hasil yang dicapai oleh siswa. Ini berulang kali, sampai apa yang telah mereka pelajari sejalan dengan persyaratan instruksi.

Di sini kita memiliki pemrograman bahasa $\mathrm{C}$ dari courseware sebagai contoh, lihatlah perancang bagaimana mencerminkan kecerdasannya. The courseware dapat menyaring dari bab pertama. Salah satu algoritma bahasa $\mathrm{C}$ klasik menggunakan animasi untuk mencapai, seperti algoritma penggambaran gelembung, algoritma seleksi sort. Penjelasan tentang guru dimasukkan ke dalam kursus. Courseware ini adalah contoh kombinasi dari teknik kecerdasan buatan sederhana di mesin cerdas dan pengambilan data dan dibantu instruksi cerdas. Prinsip pelaksanaannya adalah sebagai berikut: Menurut fokus dari setiap bagian, dan sulit dan mencerminkan siswa di kelas, itu menetapkan parameter yang berbeda $\mathrm{Wi}$, $\mathrm{C}_{\mathrm{j}}, \mathrm{H}_{\mathrm{k}}$, di mana $\mathrm{W}_{\mathrm{i}}(\mathrm{i}=1,2, \ldots \ldots \mathrm{n})$ adalah untuk nilai-nilai instruksi ketidaktepatan, $\mathrm{C}_{\mathrm{j}}(\mathrm{j}=1,2, \ldots \ldots \mathrm{n})$ adalah untuk nilai-nilai yang benar dari kesulitan instruksi, $H_{k}(k=1,2, \ldots \ldots n)$ adalah berat mencerminkan siswa mereka. Pada saat yang sama, atur fungsi $\mathrm{f}$, sesuai dengan bobot ketiga parameter ini untuk menghitung nilai $\mathrm{P}_{\mathrm{I}}=\mathrm{f}\left(\mathrm{W}_{\mathrm{i}} \cdot \mathrm{C}_{\mathrm{i} . \mathrm{H}_{\mathrm{k}}}\right)(\mathrm{I}=1,2 \ldots \ldots \mathrm{n})$, dan dengan asumsi file multimedia dari realisasi bagian yang berbeda dikompilasi ke dalam nama file yang dapat dieksekusi, masing-masing file 1.exe, file2.exe ... ..., fileM.exe (dengan asumsi bagian dokumen $\mathrm{M}$ ), sesuai dengan aturan produksi berikut:

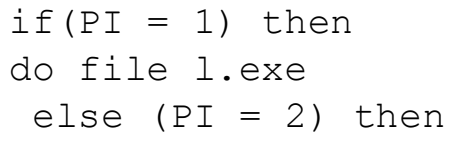


Sesuai dengan langkah-langkah di atas kita dapat mencapai fungsi mesin yang cerdas, dapat secara fleksibel menyesuaikan kemajuan instruksi sesuai dengan refleksi siswa di kelas untuk mencapai hasil pengajaran yang lebih baik.

\section{Perancangan Sistem ICAI}

Proses instruksi adalah proses pemikiran yang kompleks dari pembelajaran dan pembelajaran, itu membutuhkan keahlian dan pengalaman guru mereka, setelah absorpsi, penjelasan, penalaran, contoh, dan integrasi yang dapat kami selesaikan. Sistem pakar berbasis tugas instruksi didasarkan pada karakteristik, kelemahan dan pengetahuan dasar siswa, menggunakan program instruksi yang paling tepat dan metode instruksi untuk siswa instruksi dan konseling. Oleh karena itu, dari perspektif kecerdasan buatan, instruksi dibantu komputer sebenarnya adalah "sistem pakar" dengan sistem komputer yang membantu para guru untuk mengajar dan siswa untuk belajar. Dengan demikian, pengenalan kecerdasan buatan di CAl adalah bahwa untuk menggunakan metode sistem pakar, alat, untuk membangun $\mathrm{CAl}$ cerdas (ICAI). Fitur utama dari sistem pakar adalah: fitur modifikasi diagnostik dan debugging, antarmuka manusia-mesin yang baik.

Di CAl cerdas, ide-ide instruksi, metode, konten pembelajaran dapat diekspresikan dengan bentuk-bentuk pengetahuan. Bagaimana memecahkan representasi yang diformalkan dari pengetahuan dan akses dan pengetahuan adalah teknologi inti dari kecerdasan buatan, salah satu yang menghadapi masalah AI ke dalam bidang teknologi pendidikan. Basis pengetahuan adalah dasar dari perwujudan penalaran berbasis pengetahuan dan sistem pakar, kita dapat menggunakan basis pengetahuan untuk membangun lingkungan yang cerdas untuk ICAI, dalam basis pengetahuan, konten instruksi dapat diungkapkan oleh fakta dan aturan dan disimpan dalam basis pengetahuan, instruksi dan proses belajar adalah pengetahuan penalaran untuk basis pengetahuan, dan akhirnya sampai pada hasil yang diinginkan. Sebagai sistem pakar terutama disusun oleh basis pengetahuan dan mesin inferensi, dan oleh karena itu, juga teknologi inti dari sistem instruksi dibantu komputer cerdas. Secara umum, sebagian besar desain sistem ICAI harus memperhatikan konten berikut:

- Dasar pengetahuan. Ini adalah integrasi dari database multimedia dan teknik kecerdasan buatan, di ICAI, basis pengetahuan termasuk konten instruksi dan sumber daya lain yang akan dipilih oleh para ahli sistem pengambilan keputusan. Berbagi pengetahuan sumber daya instruksi juga dapat dilakukan pada basis pengetahuan, dan dapat memperbarui, memperbaiki pengetahuan, untuk mengurangi desain skrip dan pemeliharaan sejumlah besar perubahan pekerjaan.

- Modul Siswa. Modul ini digunakan untuk merekam situasi belajar siswa, mengumpulkan siswa belajar dari semua aspek informasi sehingga sistem pakar secara otomatis menilai pembelajaran siswa dan memberikan rekomendasi belajar dan konseling individual.

- Modul pengambilan keputusan ahli. Modul ini dapat dianggap sebagai mesin inferensi dalam sistem pakar yang menyediakan pembelajaran siswa sesuai dengan model siswa dan tiba metode instruksi cerdas dan strategi instruksi melalui pencarian dan penalaran sistem cerdas; yang dapat menilai pembelajaran siswa, juga dapat menganalisis minat dan kebiasaan masa lalu dalam pembelajaran siswa untuk memprediksi kebutuhan pengetahuan siswa dan sering kesalahan, konten pembelajaran yang berbeda secara dinamis, metode pembelajaran cocok dengan siswa yang berbeda, secara cerdas menganalisis alasan siswa yang membuat kesalahan. dan kemudian ditargetkan ke saran instruksi yang masuk akal, saran belajar dan metode peningkatan, tidak hanya meningkatkan kepuasan belajar siswa dan merangsang semangat siswa untuk belajar, tetapi juga memberikan guru dasar obyektif untuk instruksi dan metode ilmiah. 
- Modul Antarmuka Cerdas. Untuk menggunakan pengenalan karakter, pengenalan suara, teknologi pemahaman bahasa alami memungkinkan siswa untuk dialog manusia-mesin dengan bahasa alami dan "tutor cerdas".

Sistem ICAI yang baik harus mampu mengimplementasikan ide-ide pengajaran, strategi pengajaran, pendidikan kepatuhan, psikologi dan hukum. Untuk mencapai tujuan yang sempurna dari sistem ICAI, dalam jangka pendek, tugasnya masih sangat sulit. Karena sistem ICAI, setelah semua, disiplin yang berhubungan dengan komputer (terutama teknologi kecerdasan buatan) terlibat dalam pendidikan, psikologi kognitif dan sistem pengetahuan terpadu, segala jenis disiplin yang, khususnya dalam pengembangan teknik kecerdasan buatan untuk ICAI akan mempengaruhi kecepatan proses pengembangan. Namun, justru karena karakteristik multi-disiplin, yang membuatnya lebih menarik, lebih menjanjikan, meskipun ICAI domestik baru saja dimulai, tetapi pasar pendidikan yang luas dan aplikasi masa depan dan permintaan yang kuat untuk perkembangan zaman, akan mempromosikan ICAI perkembangan yang cepat.

\section{BeberaPa CONTOH SISTEM ICAI}

A. Kombinasi dengan Teknologi Jaringan

Dengan pesatnya perkembangan teknologi multimedia dan jaringan internet, aplikasi pendidikan multimedia dan jaringan internet semakin terintegrasi, CAl tidak hanya pintar, pada pengembangan tunggal, yang mau tidak mau juga ke jaringan multidimensi pengembangan ruang. Saat ini, banyak sistem pendidikan multimedia jaringan berbasis internet sedang digunakan, mereka memanfaatkan keuntungan dari jaringan untuk menyelesaikan pembelajaran online, diskusi real-time, pengujian online, berbagai tugas instruksi. Untuk menggabungkan $\mathrm{CAl}$ jaringan dan $\mathrm{CAl}$ intelijen dan saling melengkapi, akan membangun insinyur sistem baru.

\section{B. Penggunaan Teknologi Agen Cerdas}

Penerapan teknologi Inteligensi Buatan dalam ICAl tidak hanya mencerminkan pengenalan model siswa dan mekanisme penalaran pengetahuan dalam sistem pengajaran multimedia, juga dapat memainkan peran dalam penelusuran "navigasi cerdas", teknologi "agen cerdas" alih-alih guru, siswa belajar dan mencari. Teknologi agen adalah teknologi baru dari bidang ilmu komputer dalam kecerdasan buatan berkembang dengan cepat. Ia mampu secara mandiri dan terus menerus berubah secara dinamis, untuk berjalan di Agen lingkungan yang lain dan untuk berinteraksi dengan entitas lingkungan.

Dalam CAl, para siswa dapat menggunakan Pencarian Agen yang efektif mencari pengetahuan, bimbingan, karena fungsi belajar mandiri yang tersedia yang dapat mengambil inisiatif dan ruang informasi yang efisien dari pengguna Internet menemukan dan mengumpulkan informasi yang dibutuhkan. Jadi, membantu memecahkan kueri yang cocok menggunakan satu kata kunci, munculnya sejumlah besar informasi yang tidak relevan karena mesin telusur, akurasi pengambilan informasi yang rendah. Teknologi "agen cerdas" diperkenalkan ke ICAI, yang akan memungkinkan guru dan siswa untuk meningkatkan efisiensi pengetahuan pilih, memperkuat pembelajaran interaktif dan inisiatif belajar mandiri dalam pengajaran dan proses belajar.

\section{Pembelajaran Jarak Jauh}

Kombinasi CAl jaringan, CAl cerdas, dan Kolaborasi multi-Agen dapat mencapai mode pembelajaran jarak jauh yang sesungguhnya. Jaringan $\mathrm{CAl}$ menyediakan kemungkinan implementasi untuk Pembelajaran Jarak Jauh, CAl cerdas juga membuat instruksi dan pembelajaran bersifat interaktif, tidak buta, dan efisien; sementara Agen, dibandingkan dengan ICAI, dapat memainkan peran yang lebih fleksibel dan lebih beragam dalam kecerdasan. Ciri-ciri Kolaborasi multi-Agen, tidak hanya dapat 
sebagai agen guru untuk memberikan bimbingan bagi siswa untuk belajar, tetapi juga dapat berfungsi sebagai lembaga siswa, mendukung pembelajaran siswa, dapat menjadi pembelajaran, komunikasi, proses kolaboratif dalam berbagai dari agen. Dengan demikian, dengan keunggulan berbagai fitur pembelajaran jarak jauh memiliki prospek luas untuk pengembangan.

\section{Penerapan Virtual Reality}

Realitas virtual (disingkat VR) juga disebut realitas buatan. Kombinasi teknologi multimedia, teknologi simulasi, dan teknologi komputer menghasilkan dunia buatan interaktif, masih tidak dapat dipisahkan dari bidang studi kecerdasan buatan. Tujuan dasarnya adalah untuk mencapai pengalaman kehidupan nyata dan interaksi manusia-komputer berdasarkan alam. Dalam alat bantu pembelajaran, gunakan lingkungan virtual untuk menunjukkan pengoperasian tujuan instruksi, kebanyakan orang tidak dapat mengalami skenario.

Dengan terus-menerus memperdalam penelitian, untuk mencapai "realitas virtual" teori telah membuat kemajuan besar, telah ada "QTVR (Quick Time VR)" sistem, karena tingginya biaya VR, QTVR tampak lebih praktis, menggunakan teknologi fotografi panorama untuk menghasilkan adegan virtual, untuk mewujudkan pengamatan terhadap objek tiga dimensi dan tiga dimensi dalam kisaran penuh, hanya pada mouse biasa, keyboard dapat menyelesaikan semua operasi dalam keseluruhan proses. Oleh karena itu, teknologi telah membuka jalan populer untuk "realitas virtual".

\section{KeSIMPULAN.}

Teknologi kecerdasan buatan telah secara bertahap diterapkan pada instruksi dibantu komputer, terkait erat dengan modernisasi instruksi. Pengembangan teknologi kecerdasan buatan akan memainkan peran luar biasa dalam mempromosikan pengembangan ICAI. Dalam beberapa tahun terakhir, para peneliti AI telah mencoba untuk memungkinkan siswa untuk menerima pengetahuan baru dari proses "pembelajaran dukungan". Dalam aspek lain dari instruksi, teknologi kecerdasan buatan juga dapat membuat model penalaran manusia, alat belajar, dan banyak penggunaan lainnya, menunjukkan kegunaan yang lebih baik dan lebih baik. Dengan perkembangan Internet, aplikasi teknologi virtual reality yang luas, ICAI juga akan lebih ditingkatkan.

\section{REFERENSI}

[1] Zhang Sen. Multimedia CAl courseware basic principles and production technology [M]. Beijing: Beijing University of Aeronautics and Astronautics Press, 2000.

[2] Wang Wan-sen. Principles and Applications of Artificial Intelligence [M]. Beijing: Electronic Industry Press, 2000.

[3] R - Brown Johnson. Past, present and future oftheinstructionmodel[J] the United States Educational Technology .2007(2) :36-40.

[4] Lin Yao-Rui, Ma Siu-ping. Artificial Intelligence [M]. Beijing: Tsinghua University Press.

[5] Zheng Renjie. Practical Software Engineering [M]. Beijing: Tsinghua University Press, 2005

[6] Fu Jing Sun, CAl Zi-xing, XU Guang-You. Artificial Intelligence and its applications [M]. Beijing: Tsinghua University Press, 2007

[7] RS Pressman. Software Engineering [M]. Beijing: National Defense Industry Press, 2008

[8] Bergamaschi S, Castano S. Vincini M, Semantic Integration of Semistructured and Data Sources [J]. SIGMOD Record, 2009,28 (1) :5459. 